\title{
A Causal Model to Compare the Extent of Undergraduates'- Postgraduates' Impact on Unemployment in Uganda
}

\author{
Victoria Kakooza ${ }^{1}$, Robert Wamala ${ }^{2}$, James Wokadala ${ }^{3} \&$ Thomas Bwire $^{4}$ \\ ${ }^{1}$ PhD Student, School of Statistics, College of Business and Management Science, Makerere University. Kampala, \\ Uganda \\ ${ }^{2}$ Deputy Director, Directorate of Research and Graduate Training, Makerere University,Kampala, Uganda \\ ${ }^{3}$ Lecturer- School of Statistics, College of Business and Management Science, Makerere University.Kampala, \\ Uganda \\ ${ }^{4}$ Economic Research Function, Bank of Uganda, Uganda \\ Correspondence: Victoria Kakooza, PhD Student, School of Statistics, College of Business and Management Science, \\ Makerere University. Kampala, Uganda. E-mail: victoriakakooza@gmail.com
}

Received: June 5, 2019

doi:10.5430/ijhe.v8n5p110
Accepted: August 19, 2019

Online Published: August 21, 2019

URL: https://doi.org/10.5430/ijhe.v8n5p110

\begin{abstract}
The combination of technological unemployment and oversupply of graduates has increased competition in the labour markets. Postgraduates have been noted to hold more than one job and in some cases apply for jobs meant for undergraduates. Could this imply that post graduates have created more overall unemployment than undergraduates have, in the Ugandan labour market? This is the novel of this study. This was accomplished by a statistical model that comparatively analysed the bi-causal effect of postgraduates on unemployment; versus effect of undergraduates on unemployment. As such, the study utilised Uganda's secondary data from 1991 to 2017, and employed the Vector Error Correction (VECM) model. The results of the study showed the existence of a long run impact of both the postgraduates and undergraduates on overall unemployment, but an insignificant impact in the short run. The postgraduates had a greater impact on unemployment in the long run, than the undergraduates. The study therefore reveals an affirmative answer to the aforementioned question.
\end{abstract}

Keywords: undergraduates, postgraduates, Uganda, Vector error correction model

\section{Introduction}

The scrutiny of the relationship between overall unemployment and different education levels stems from the opinion that postgraduates have created more unemployment than what undergraduates have caused. Postgraduates have been noted to hold more than one job (Suganya, 2019), and in some cases apply for jobs meant for undergraduates. Others that are already in the job market take long to be absorbed in higher ranks post graduate education doesn't imply instantaneous promotion (Paresashvili, Nikvashvili, Pirtskhalaishvili, \& Kharadze, 2019). This triangular nature of ranks in the labour market has caused the perception that the increasing number of postgraduates, has resulted into more unemployment than that caused by undergraduates. In developing countries, unemployment has been documented to be highest among those holding higher education qualifications (Akinyoade, 2019). Hence, the growth of postgraduates to a nation's labour market could be a bonus or a burden, which this study intends to establish.

Higher education is mainly sought for better employment (Higgs, Crisp, \& Letts, 2019); or even secure current employment (O'Shea \& Delahunty, 2019). This causes one to envision immediate employment after graduating. However, guaranteed employment is still questionable due to the current oversupply of both undergraduates and postgraduates (MES, 2017; Kagan, \& Diamond, 2019). The employment requirements have been raised with the majority of formal jobs requiring a degree as a minimum qualification. This has affected all workers in the labour market, and not just the graduates. Higher education graduates therefore have not only caused graduate unemployment, but overall unemployment. Even the highly skilled are insecure in the labour market (Schwander,2019) The situation in Uganda calla for attention as those without higher education have sought employment in Asian countries, like Saudi Arabia, Jordan, Iran, to mention a few. 
Combining this with technological unemployment that is slowly taking root in the banking sector, industries, and even agriculture; the risks of unemployment for workers has increased. Technological unemployment has been evidenced in form of Internet banking, Automatic Teller machines, analogue news, social media marketing/ advertising; as well as different kinds of automation and machinery in industries and in agricultural farms. Uganda's economy has become jobless (Bbaale, 2013). The workers in the job market face job replacement by technology, artificial intelligence, or even more qualified workers (Peters, Jandric, \& Mean,. 2019). The question is whether highly educated have helped by creating jobs or worsened the situation. As a result, some undergraduates have sought for postgraduate education hoping that they will reduce their chances of unemployment. Whether this is achieved or not, is a subject of research. This calls for a bi-causal study, which is the novel of this paper.

\section{Literature Review}

Capital accumulation has been noted as a major determinant of unemployment (Heimberger, 2019). This has resulted in researchers endeavoring to investigate the effect of various education levels on unemployment. Some have found that people with higher education skills had lower unemployment rates than those with lower education Patel, (2019) in the UK. In some cases, postgraduates hold two or more jobs (Suganya, 2019), with lower entrepreneurship intentions. During a comparative study of postgraduate and grade students, Perez (2016) found that those with Degree were more optimistic and had a greater desire to start businesses than the Masters students. This could imply that the postgraduate education reduces the unemployment rate of the holder but could increase unemployment among other workers in the labour market.

Besides, other researchers found higher unemployment rates among those with higher education (Bakkabulindi, 2006) in Uganda. The question is whether this applies to both undergraduates and post graduates. In some places postgraduates especially doctorates, although employed, have found it difficult to come by appropriate employment (Townsend, \& Brookins, 2016; Ermini, Papi, \& Scaturro, 2017; Gaeta et al., 2017) as many non-academic employers have a little yearning and appreciation for research. Post graduate employability has further been devalued by assumed lower quality as a result of cram-work, and higher cost of employing postgraduates, that does not give justification for employing postgraduates in developing countries (Zhou, 2019). Researches being the central virtue of post graduate education, some postgraduates in some countries have opted for migration in search of appropriate greener pastures (Alfano, D'Uva, De Simone, \& Gaeta, 2019). This may not be so in Uganda, as most postgraduates have extended responsibilities and attachment. So the competition of jobs in the labour market cannot be relieved.

In reviewing literature, studies on the effects of higher education on unemployment do not explicitly differentiate between the effect of higher education on unemployment at either undergraduate or postgraduate level. This could possibly be resulting from the previous knowledge that postgraduates are few in number, and therefore their effect cannot be significantly felt in the labour markets or economy. This however has changed. Over the years, there has been a structural change in the higher education output over that included noticeable increments in the number of postgraduates; warranting a study. In addition, in studying the relationship between graduates and unemployment, several studies have focused on graduate unemployment (e.g. Van Broekhuizen, 2016; Ponge, 2013); and not overall unemployment which is the intention of this study. In addition, this study intends to establish the short run and long run impacts, a fact that has been forgotten in prior studies.

\section{Methodology}

\subsection{Model Specification}

Econometricians tend to use a methodology basing on the data and its statistical characteristics; therefore The Vector Error Correction (VECM) model was selected for analyzing the aforementioned impact. In acknowledging the fact that unemployment depends on both supply and demand factors; the model exhibited that. The demand factors included; Gross capital Formation (GCF); Foreign Direct Investment (FDI), and Gross Domestic product (GDP), while the supply factors were the postgraduates and undergraduates. Annual time series from 1991 to 2017 on the demand factors and unemployment were obtained from the World Bank database; while that on supply factors was obtained from a sample of three universities in Uganda. The annual data was later computed into quarters using the MS-excel package.

\subsection{Empirical Model}

In a VECM setting, the study variables are all endogenous. The model is run with the lagged values of all the endogenous variables are regressed as independent variables in the model system. The VECM is often stated as equation 1. 


$$
\Delta X_{t}=\Gamma_{1} \Delta X_{t-1}+\Gamma_{2} \Delta X_{t-2}+\cdots+\Gamma_{k-1} \Delta X_{t-k-1}+\prod X_{t-1}+\varphi \Delta_{t}+\varepsilon_{t}
$$

Where $\mathrm{k}$ is the optimal lag length.

In a reduced form, VECM is

$$
\Delta X_{t}=\mu_{0}+\sum_{i=1}^{k-i} \Gamma_{i} \Delta X_{t-i}+\prod X_{t-1}+\varphi \Delta_{t}+\varepsilon_{t}
$$

Where $\prod=\sum_{i=1}^{k-i} A_{i}-I$; and $\Gamma_{i}=-\sum_{j=i+1}^{k-i} A_{j}$

When $\mathrm{Xt}$ has co-integration relationship, the equation 1 can be rewritten as

$$
\Delta X_{t}=\alpha \beta^{\prime} X_{t-1}+\sum_{i=1}^{p-1} \Gamma_{i} \Delta X_{t-i}+\varepsilon_{t}
$$

Where $\beta^{\prime} X_{t-1}$ is the Error Correction Term (ECT).

\section{Results}

\subsection{Test for Integration}

As a prerequisite for the VECM analysis, the ADF test is run to make ensure that the variables under study are all integrated of order one. When a series is stationary with no difference, the variable order of integration is zero I (0). If it becomes stationary after first difference, the variable order of integration is one I (I). The results for integration are presented in Table 1.

Table 1. Test Results for Integration

\begin{tabular}{lllll}
\hline Variables & Level & \multicolumn{3}{l}{ First Difference } \\
\cline { 2 - 5 } & Value & P-value & Value & P-value \\
\hline UNEMPLOYMENT & -1.834313 & 0.3622 & -15.16652 & 0.0000 \\
Postgraduates & -1.480704 & 0.5396 & -10.21135 & 0.0000 \\
Undergraduates & -1.522460 & 0.5185 & -9.995634 & 0.0000 \\
GDP_GROWTH & -1.628523 & 0.4645 & -12.93956 & 0.0000 \\
FDI_M_DOLLARS & -1.412729 & 0.5735 & -14.62538 & 0.0000
\end{tabular}

Note: Estimate were obtained using the Augmented Dickey Fuller Tests. UNEMPLYT denotes unemployment, Gross Domestic product (GDP), post graduates (post graduates), undergraduates (unde graduates); Gross capital Formation (GCF),; FDI_M_DOLLARS denotes Foreign Direct Investment in million US dollars.

The findings of the unit root test showed that all the variables at level had unit roots, yet when differenced once, did not have unit roots. This implied that ADF test affirmed that all study variables were integrated of order one $I(1)$, at the significance level of $10 \%, 5 \%$, and $1 \%$. This is illustrated in Table 1 .

\subsection{Optimal Lag Selection}

Before further tests, the Sequential modified LR test statistic (LR), Schwarz information criterion (SIC), Hannan-Quinn information criterion (HQ), and Akaike information criterion (AIC), tests; were applied to determine the optimal lag. This is shown Table 2.

Table 2. Results of the Optimal Lag Selection

\begin{tabular}{lllllc}
\hline Model & Lag & LR & AIC & SIC & HQ \\
\hline UNEMPLYT =f(POST, UNDER, GCF, & 0 & NA & 2.774581 & 3.016522 & 2.844251 \\
GDP_GROWTH, FDI_M_DOLLARS) & 1 & $38.07829^{*}$ & $0.947589^{*}$ & $1.237919^{*}$ & $1.031194^{*}$ \\
\hline
\end{tabular}

Note. UNEMPLYT denotes unemployment, Gross Domestic product (GDP), post graduates (post graduates), undergraduates (unde graduates); Gross capital Formation (GCF),; FDI_M_DOLLARS denotes Foreign Direct Investment in million US dollars. Sequential modified LR test statistic (LR), Akaike information criterion (AIC), Schwarz information criterion (SIC), and Hannan-Quinn information criterion (HQ).

The optimal lag determined by the test criteria was one, as illustrated in Table 2.

4.3 Johansen Co-Integration Test

Co-integration characterises integrating variables to have a common trend in the long-run. 
This test determines the number of vectors that are co-integrated in the model. It is mainly tested using the Trace Statistic and the maximum Eigen value statistics. The comparison between the Probability value and the Critical Value is made. Where the Probability value is greater than the critical value, we fail to reject the null hypothesis.

Table 3. Results for the Co-integration Test

\begin{tabular}{|c|c|c|c|c|c|c|}
\hline \multirow[t]{3}{*}{ Regression Model } & Data Trend: & None & None & Linear & Linear & Quadratic \\
\hline & \multirow[t]{2}{*}{$\begin{array}{l}\text { Test } \\
\text { Type }\end{array}$} & $\begin{array}{l}\text { No } \\
\text { Intercept }\end{array}$ & Intercept & Intercept & Intercept & Intercept \\
\hline & & No Trend & No Trend & No Trend & Trend & Trend \\
\hline 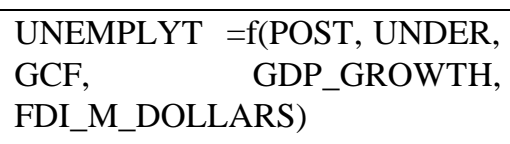 & $\begin{array}{l}\text { Trace } \\
\text { Max-Eig }\end{array}$ & 1 & 1 & 1 & 0 & 1 \\
\hline \multicolumn{7}{|c|}{$\begin{array}{l}\text { Note: UNEMPLYT denotes unemployment, Gross Domestic product (GDP), post graduates (post graduates), } \\
\text { undergraduates (unde graduates); Gross capital Formation (GCF),; FDI_M_DOLLARS denotes Foreign Direct } \\
\text { Investment in million US dollars. }\end{array}$} \\
\hline \multicolumn{7}{|c|}{$\begin{array}{l}\text { The Eigen and Trace tests in Table } 3 \text { revealed that the number of co-integrating equations for the model was one, a } \\
\text { the } 5 \% \text { level of significance. This means the variables under study have both a short run and long run effects } \\
\text { Therefore the VECM methodology was used, since it takes into consideration both long-run and short-run } \\
\text { adjustments in the same equations of the model. }\end{array}$} \\
\hline
\end{tabular}

\subsection{Estimation Results for the VECM Analyses}

Having done all the prior tests, the next step involved running the VECM analysis.

The VECM results are presented in Table 4. Here the value of the coefficients, their standard errors, and their $\mathrm{t}-$ statistics are also presented.

Table 4. Regression Results

\begin{tabular}{lc} 
Cointegrating Eq: & CointEq1 \\
\hline UNEMPLYT(-1) & 1.000000 \\
POST(-1) & -0.008905 \\
& $(0.00655)$ \\
& {$[-1.35887]$} \\
& 0.001483 \\
UNDER(-1) & $(0.00026)$ \\
& {$[5.60961]$} \\
& 0.008977 \\
GCF(-1) & $(0.00102)$ \\
& {$[8.83595]$} \\
& 1.436999 \\
GDP_GROWTH(-1) & $(0.38369)$ \\
& {$[3.74521]$} \\
FDI_M_DOLLARS(-1) & -0.073971 \\
& $(0.00510)$ \\
& {$[-14.5037]$} \\
C & -11.02380 \\
\hline
\end{tabular}




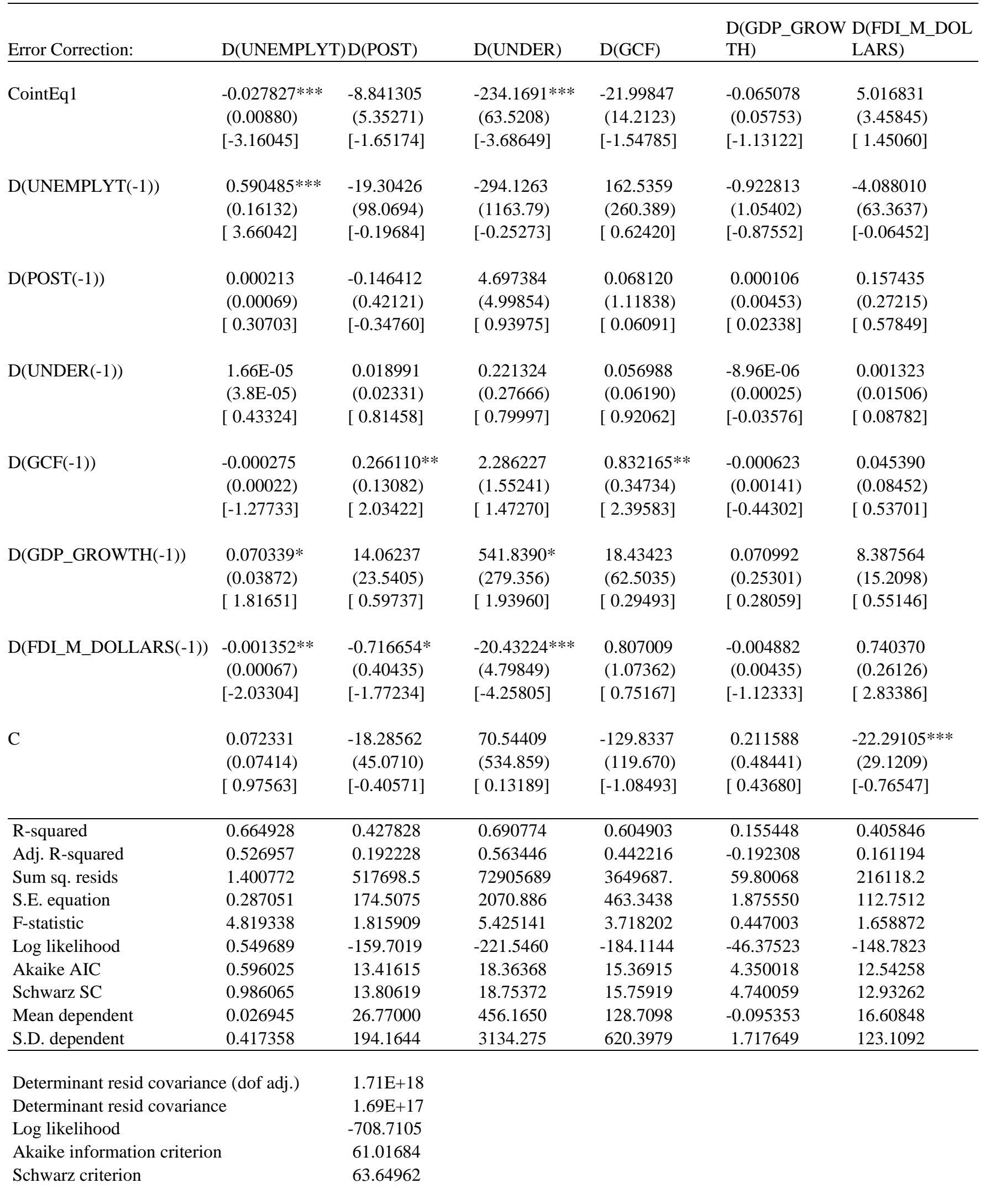

Note: UNEMPLYT denotes unemployment, Gross Domestic product (GDP), post graduates (post graduates), undergraduates (unde graduates); Gross capital Formation (GCF),; FDI_M_DOLLARS denotes Foreign Direct Investment in million US dollars. 
Figures denote the coefficients, standard errors(), and t-statistics[]. $\Delta$ denotes first difference, -1 denotes lag 1,-2 denotes lag $2 . * * *$ and $* * * \quad$ means significant at $10 \%, 5 \%$ and $1 \%$ respectively.

$\mathrm{D}($ UNEMPLYT $)=\mathrm{C}(1) *($ UNEMPLYT $(-1)-0.0089046891315 *$ POST $(-1)+0.00148294419342 *$ UNDER $(-1)+$ $0.00897657285447 * \mathrm{GCF}(-1)+1.43699913304 *$ GDP_GROWTH(-1) - 0.0739710375611*FDI_M_DOLLARS(-1) $11.0237994504)+\mathrm{C}(2) * \mathrm{D}(\mathrm{UNEMPLYT}(-1))+\mathrm{C}(3) * \mathrm{D}(\mathrm{POST}(-1))+\mathrm{C}(4) * \mathrm{D}(\mathrm{UNDER}(-1))+\mathrm{C}(5) * \mathrm{D}(\mathrm{GCF}(-1))+$ $\mathrm{C}(6) * \mathrm{D}($ GDP_GROWTH(-1)) + C(7)*D(FDI_M_DOLLARS(-1)) + C(8)

$\mathrm{D}(\mathrm{POST})=\mathrm{C}(9) *($ UNEMPLYT $(-1)-0.0089046891315 * \mathrm{POST}(-1)+0.00148294419342 * \operatorname{UNDER}(-1)+$ $0.00897657285447 *$ GCF(-1) + 1.43699913304*GDP_GROWTH(-1) - 0.0739710375611*FDI_M_DOLLARS(-1) $11.0237994504)+\mathrm{C}(10) * \mathrm{D}(\mathrm{UNEMPLYT}(-1))+\mathrm{C}(11) * \mathrm{D}(\mathrm{POST}(-1))+\mathrm{C}(12) * \mathrm{D}(\mathrm{UNDER}(-1))+\mathrm{C}(13) * \mathrm{D}(\mathrm{GCF}(-1))$ + C(14)*D(GDP_GROWTH(-1)) + C(15)*D(FDI_M_DOLLARS(-1)) + C(16)

$\mathrm{D}(\mathrm{UNDER})=\mathrm{C}(17) *(\mathrm{UNEMPLYT}(-1)-0.0089046891315 * \mathrm{POST}(-1)+0.00148294419342 * \mathrm{UNDER}(-1)+$ $0.00897657285447 * \mathrm{GCF}(-1)+1.43699913304 *$ GDP_GROWTH(-1) - 0.0739710375611*FDI_M_DOLLARS(-1) $11.0237994504)+\mathrm{C}(18) * \mathrm{D}(\mathrm{UNEMPLYT}(-1))+\mathrm{C}(19) * \mathrm{D}(\mathrm{POST}(-1))+\mathrm{C}(20) * \mathrm{D}(\mathrm{UNDER}(-1))+\overline{\mathrm{C}}(21) * \mathrm{D}(\mathrm{GCF}(-1))$ $+\mathrm{C}(22) * \mathrm{D}($ GDP_GROWTH(-1) $)+\mathrm{C}(23) * \mathrm{D}($ FDI_M_DOLLARS $(-1))+\mathrm{C}(24)$

$\mathrm{D}(\mathrm{GCF})=\mathrm{C}(25) *($ UNEMPLYT $(-1)-0.0089046891315 *$ POST $(-1)+0.00148294419342 * \mathrm{UNDER}(-1)+$ $0.00897657285447 * \mathrm{GCF}(-1)+1.43699913304 *$ GDP_GROWTH(-1) - 0.0739710375611*FDI_M_DOLLARS(-1) $11.0237994504)+\mathrm{C}(26) * \mathrm{D}(\mathrm{UNEMPLYT}(-1))+\mathrm{C}(27) * \mathrm{D}(\mathrm{POST}(-1))+\mathrm{C}(28) * \mathrm{D}(\mathrm{UNDER}(-1))+\mathrm{C}(29) * \mathrm{D}(\mathrm{GCF}(-1))$ $+\mathrm{C}(30) * \mathrm{D}($ GDP_GROWTH(-1)) + C(31)*D(FDI_M_DOLLARS(-1)) + C(32)

$\mathrm{D}($ GDP_GROWTH $)=\mathrm{C}(33) *($ UNEMPLYT $(-1)-0.0089046891315 *$ POST $(-1)+0.00148294419342 *$ UNDER $(-1)$ $+0.00897657285447 * \mathrm{GCF}(-1)+1.43699913304 * \mathrm{GDP} \_\mathrm{GROWTH}(-1)-0.0739710375611 *$ FDI_M_DOLLARS(-1) $-11.0237994504)+\mathrm{C}(34) * \mathrm{D}(\mathrm{UNEMPLYT}(-1))+\mathrm{C}(35) * \mathrm{D}(\operatorname{POST}(-1))+\mathrm{C}(36) * \mathrm{D}(\mathrm{UNDER}(-1))+$ $\mathrm{C}(37) * \mathrm{D}(\mathrm{GCF}(-1))+\mathrm{C}(38) * \mathrm{D}\left(\mathrm{GDP} \_\mathrm{GROWTH}(-1)\right)+\mathrm{C}(39) * \mathrm{D}($ FDI_M_DOLLARS $(-1))+\mathrm{C}(40)$

$\mathrm{D}($ FDI_M_DOLLARS $) \quad=\quad \mathrm{C}(41)^{*}($ UNEMPLYT(-1) $-0.0089046891315 * \mathrm{POST}(-1)+$ $0.00148294419342 * \operatorname{UNDER}(-1)+0.00897657285447 * \mathrm{GCF}(-1)+1.43699913304 *$ GDP_GROWTH(-1) $0.0739710375611 *$ FDI_M_DOLLARS(-1) - 11.0237994504$)+\mathrm{C}(42) * \mathrm{D}(\mathrm{UNEMPLYT}(-1))+\mathrm{C}(43) * \mathrm{D}(\mathrm{POST}(-1))$ $+\mathrm{C}(44) * \mathrm{D}(\mathrm{UNDER}(-1))+\mathrm{C}(45) * \mathrm{D}(\mathrm{GCF}(-1))+\mathrm{C}(46) * \mathrm{D}($ GDP_GROWTH(-1) $)+\mathrm{C}(47) * \mathrm{D}($ FDI_M_DOLLARS(-1)) $+\mathrm{C}(48)$

The Error Correction Term (ECT) from Table 4 is stated as;

$\mathrm{ECT}_{\mathrm{t}}=1.000000$ UNEMPLYT $(-1)-0.008905$ POST $(-1)+0.001483$ UNDER $(-1)+0.008977$ GCF $(-1)+1.436999$ GDP_GROWTH (-1)- 0.073971 FDI_M_DOLLARS (-1) -11.02380

Equation 9, can be restated as Equation 10:

UNEMPLYT $(-1)=0.008905$ POST $(-1)-0.001483$ UNDER $(-1)-0.008977$ GCF $(-1)-1.436999$ GDP_GROWTH $(-1)+0.073971$ FDI_M_DOLLARS $(-1)+11.02380$

The adjustment speed to long run equilibrium is shown by the coefficient of -11.02380 , which is significant and negative. It indicates that the variables return to the long run equilibrium at approximately $11 \%$ rate. The equation further shows the existence of a long run relationship as shown in equation 10. From equation 11, it can be viewed that postgraduates increased unemployment by $8.9 \%$, while undergraduates reduced unemployment by $1.5 \%$ in the long run. In the short run, there is no significant causal relationship between unemployment and the two graduate levels (postgraduates and undergraduates).

\section{Discussion and Policy Recommendations}

The research objective and contribution of this study was an econometric comparative impact of postgraduates on general unemployment, versus undergraduates' impact on unemployment in Uganda, for the period between 1991 and 2017. These effects were modeled by the VECM, which gives a unique contribution of a past response of unemployment from the increased number of post- and under- graduates as well as a reverse response of the said graduates to unemployment; in both the short and long term periods. The findings of this study revealed that postgraduates and undergraduates have only a long term impact on the general unemployment in Uganda, with postgraduates having a greater impact. In particular, Postgraduates increased unemployment in the long run, which partly agrees with results from a prior study by Bakkabulindi, (2006), who found higher education in general to cause unemployment in Uganda. These findings could stem from the fact that they have difficulty in obtaining employment (Townsend, \& Brookins, 2016; Ermini, Papi, \& Scaturro, 2017; Gaeta et al., 2017). This finding aligns 
to the argument that there are few employers postgraduates, especially Doctorate holders (McCarthy\& Wienk, 2019), especially for the labour markets in developing countries, with little appreciation and demand for research.

Therefore, higher education policies to reduce unemployment in Uganda, should centre on revisiting the postgraduate curriculums, incorporating creativity, innovativeness and even inventiveness. In addition, quality needs to be ensured in postgraduate education (Angell, Heffernan, \& Megicks, 2008); as some people question the quality of postgraduates (Hui, 2019). Postgraduates have a role to play in the society. They need to concentrate on developing and maturing in their careers with the mentality of creating more jobs not the mentality of research for profit. This can be possible since the majority have employment and

are in a better position to raise capital for inventions, and innovations, in their field of specialty. Postgraduates should be mentioned as the successful employers and entrepreneurs of the labour markets, and not the less educated.

On the other hand, in this study undergraduates were found to reduce unemployment in the long run. This aligns to the findings of Aden, (2017) in Canada. This study however brings thoughtful insights to the fact that the impact of graduates on unemployment varies with the time frame. The findings therefore agrees that undergraduates may seemingly cause graduate unemployment, but not in the long run. This could explain the the robust literature on graduate unemployment in developing countries (e.g. Ogege, 2011; Oluwajodu, Greyling, Blaauw, \& Kleynhans, 2015; Ponge, 2013). The current study adds to this literature notion that "higher education reduces unemployment"; that not all categories of higher education increase unemployment; hence recognizing the heterogeneous impact of higher education on unemployment. This implies that the graduate unemployment caused by undergraduates is later corrected.

\section{Conclusion}

In summary, the discourse analysed from graduate level to unemployment, and vice- versa; continues to express concern about the urgency of handling unemployment from all fronts. Truth be told, Uganda cannot create as many jobs in the various fields as the number of graduates released into the job market annually, but unified efforts could help solve the persistent unemployment problem.

\section{Acknowledgement}

The success of this paper was made possible by the support of the Swedish government, through the Makerere university- SIDA funding.

\section{References}

Aden, I. (2017). Impact of Education on Unemployment Evidence From Canada.

Alfano, V., D'Uva, M., De Simone, E., \& Gaeta, G. L. (2019). Should I stay or should I go? Migration and job-skills mismatch among Italian doctoral recipients (No. 340). GLO Discussion Paper.

Akinyoade, A. (2019). Nigeria: education, labour market, migration. SEOA Economics.

Angell, R. J., Heffernan, T. W., \& Megicks, P. (2008). Service quality in postgraduate education. Quality Assurance in Education, 16(3), 236-254. https://doi.org/10.1108/09684880810886259

Bakkabulindi, F. (2006). Financing higher education in Uganda. Nkumba University Education Journal, 1(1), 42-59.

Bbaale, E. (2013). Is Uganda's growth profile jobless?. https://doi.org/10.5539/ijef.v5n11p105

Ermini, B., Papi, L., \& Scaturro, F. (2017). An analysis of the determinants of over-education among Italian Ph.D graduates. Italian Economic Journal, 3(2), 167-207. https://doi.org/10.1007/s40797-017-0053-3

Gaeta, HH, Ortolan, BD, Rodrigues, CFB, Cruz Costa, CR, Belchor, MN, Oliveira Toyama, D., \& Toyama, MH (2017). "METABOLIC RIDE" a conceptual evaluation tool for metabolic biochemistry teaching for graduate and postgraduate students in biological sciences and related areas. Journal of Biochemistry Teaching . https://doi.org/10.16923/reb.v15i0.702

Heimberger, P. (2019). The Impact of Labour Market Institutions and Capital Accumulation on Unemployment: Evidence for the OECD, 1985-2013 (No. 164). The Vienna Institute for International Economic Studies, wiiw.

Higgs, J., Crisp, G., \& Letts, W. (2019). Education for employability (Volume 1): The employability agenda. https://doi.org/10.1163/9789004400832

Hui, W. (2019, May). Research on the Current Situation of Academic Anomie of Postgraduates. In 2019 4th International Conference on Social Sciences and Economic Development (ICSSED 2019). Atlantis Press. https://doi.org/10.2991/icssed-19.2019.128 
Johansen, S. (1995). Likelihood-Based Inference in Cointegrated Vector Auto Regressive Models. Advanced Texts in Econometrics, Oxford University Press Inc, NewYork. https://doi.org/10.1093/0198774508.001.0001

Juselius, K. (2006). The cointegrated VAR model: methodology and applications. Oxford university press.

Kagan,C, \& Diamond, J. (2019). The Impact Agenda and Beyond. University Community Relations in the UK, 165-181. https://doi.org/10.1007/978-3-030-12984-2_7

McCarthy, P. X., \& Wienk, M. (2019). Who are the top PhD employers?.

Ministry of Finance, Planning and Economic Development (MoFPED) (2017). Background to the Budget Fiscal year 2017/18. Kampala, Uganda.

Ogege, S. O. (2011). Education and the paradox of graduate unemployment: The dilemma of development in Nigeria. African Research Review, 5(1). https://doi.org/10.4314/afrrev.v5i1.64524

Oluwajodu, F., Greyling, L., Blaauw, D., \& Kleynhans, E. P. (2015). Graduate unemployment in South Africa: Perspectives from the banking sector. SA Journal of Human Resource Management, 13(1), 1-9. https://doi.org/10.4102/sajhrm.v13i1.656

Oppong, S., \& Sachs, P. R. (2015). Managing Graduate Unemployment in Emerging Economies: Critical Analysis of the Skills Mismatch and Oversupply Theses. Polovna Brief, 1, 1-14. Patel, N. (2019). Education Levels and Employment in UK.

O'Shea, S. (2019). Mind the Gap!. Exploring the post-graduation outcomes and employment mobility of individuals who are first in their family to complete a university degree. Framing paper for 2019 Research Fellowship, 4.

Patel, N. (2019). Education Levels and Employment in UK.

Paresashvili, N., Nikvashvili, M., Pirtskhalaishvili, D., \& Kharadze, N. (2019). Career Management Peculiarities in Educational Institutions. In 17th International Conference on Social Sciences Murcia, 8-9 March 2019 (p. 212).

Peters, M. A., Jandrić, P., \& Means, A. J. (2019). Introduction: Technological Unemployment and the Future of Work. In Education and Technological Unemployment (pp. 1-12). Springer, Singapore. https://doi.org/10.1007/978-981-13-6225-5_1

Ponge, A. (2013). Graduate unemployment and unemployability in Kenya: transforming university education to cope with market demands and the lessons for Africa. International Journal of Social Science Tomorrow, 2(3), 1-12.

Schwander, H. (2019). Labor market insecurity among the middle class: a cross-pressured group. Political Science Research and Methods, 1-6. https://doi.org/10.1017/psrm.2019.11

Suganya, K. (2019). The Factors Affecting Work Life Balance among Post Graduate Students in Eastern Province, Sri Lanka. Asian Journal of Economics, Business and Accounting, 1-9. https://doi.org/10.9734/ajeba/2019/v11i130118

Townsend, R. B., \& Brookins, J. (2016). The Troubled Academic Job Market for History. Perspectives on History, 54, 64-72.

Van Broekhuizen, H. (2016). Graduate unemployment and higher education institutions in South Africa. Bureau for Economic Research and Stellenbosch Economic Working Paper 08, 16.

Vijesandiran, S., \& Vinayagathasan, T. (2015). Dynamic relationship between human capital and economic growth in Sri Lanka: A co-integration analysis. Asian Online Journal, 2(2), 20-29.

World Bank (2018). World Bank Open data - World Bank Group.

Zhou, G. (2019). Postgraduate Education and Degree System Reform. In Education Policy and Reform in China (pp. 145-156). Palgrave Macmillan, Singapore. https://doi.org/10.1007/978-981-13-6492-1_12 